\title{
Fleas in nests of the White-throated Dipper Cinclus cinclus in Norway
}

\author{
Trond Øigarden ${ }^{1}$, Reidar A. Mehl² \& Kurt Jerstad ${ }^{3}$ \\ 'Prestegarden, NO-2910 Aurdal, Norway; trondoi@online.no \\ ${ }^{2}$ Moserabben 7, NO-3075 Berger, Norway \\ ${ }^{3}$ Aurebekksveien 61, NO-4516 Mandal, Norway.
}

\begin{abstract}
We collected nest material from six White-throated Dipper Cinclus cinclus nests in 2006 and from 14 nests in 2007. Eight nests were located in Hedmark, one in Akershus and 11 in Vest-Agder. In addition, we also include results from material sampled in 1922 (one nest from Nordland), 1969 (three nests from Akershus) and 1971 (one nest from Møre og Romsdal). In the material, we recorded three species of bird fleas. The hen flea Ceratophyllus gallinae and the moorhen flea Dasypsyllus gallinulae were the most common ones; in addition, we found Ceratophyllus garei in one nest. In the material from one nest, we found an extremely high number of $D$. gallinulae, 3740 specimens dispersed out of the nest material.
\end{abstract}

Key words: nest parasites; Siphonaptera; Cinclidae

\section{INTRODUCTION}

In Norway 57 species of fleas (Siphonaptera) have been recorded. Twenty one (Mehl 1967a, 1967b, 1968, 1970b, 1992 and unpubl. data) of these species have birds as their host; the commonest fleas are Ceratophyllus gallinae Schrank, 1803 (the hen flea), Ceratophyllus garei Rothschild, 1902 and Dasypsyllus gallinulae Dale, 1878 (the moorhen flea). Mehl (unpubl. data) has in his data registered fleas in the nest material from 61 Norwegian bird species: $C$. garei from 40 species, C. gallinae from 37 species and $D$. gallinulae from 14 species.

Fleas are largely confined to the host's nest, except when dispersing. Most overwinter as imagos in the pupal cocoon, in or near the nest, and the main dispersal probably occurs in the spring at the beginning of the birds breeding season. Two overlapping flea generations are produced between the host's egg-laying period and fledging of its young. First generation adult fleas appear around hatching time of the nestlings and join the surviving founder fleas for larval production. At the end of the nestling period, the first generation and second generation spin cocoons and remain dormant for several months. These offspring will eventually infest a new host at the beginning of its breeding attempt (Tripet \& Richner 1999a).

The hen flea $C$. gallinae is a common ectoparasite of cavity-nesting birds in the Western Palearctic, with the hole-nesting tits as the main hosts (Tripet \& Richner 1997a). Several studies have been performed on the effect of the parasites on their hosts, both on nestlings and parents (see for example Richner et al 1993, Brown et al. 1995, Tripet \& Richner 1997b, Heeb et al 2000, Fitze et al 2004, Tomas et al. 2007). Most studies show that the parasites have a significantly negative effect on their hosts. Some studies have examined the behaviour of the hosts to avoid fleas. Oppliger et al. (1994) offered great Great Tits Parus major a choice between an infested and a parasite-free nest-box, and they chose the one without parasites. When detecting the presence of ectoparasites in their nests, hosts can avoid parasite contact by changing nest sites (Rytkönen et al. 1998). Alternatively, birds can remove old nest material prior to nest building and thus reduce ectoparasite loads (Pacejka et al. 1998). See also Mappes et al (1994), they found that Pied Flycatchers Ficedula hypoleuca preferred nest boxes with old nest material. Some large counts from individual nests are recorded, such as at least 5754 C. gallinae from a nest of a doublebrooded Coal Tit Periparus ater (Rheinwald 1968), while $D$. gallinulae populations have not been reported to approach these sizes. From a Grey Wagtail Motacilla cinerea nest, 608 D. gallinulae individuals are noted (Peus 1968). Birds that nest in holes in banks or trees, like Sand Martins Riparia riparia and Blue Tits Cyanistes caeruleus, often have large numbers of fleas (Tyler \& Ormerod 1994). The behaviour with reuse of nests allows for easy transmission of parasites (Møller \& Erritzøe 1996).

Nests of White-throated Dipper Cinclus cinclus (hereafter Dipper) are often in holes or dark enclosed 
sites, and the nest is domed with only a 5-7 cm entrance hole. Dipper nests may be re-used for successive broods in a season or even in successive seasons, and old nests may be used for roosting in the autumn and winter. Therefore, Dipper nests provide ideal conditions for fleas to breed and to spread from one bird to another. Examination of Welsh Dipper nests at the end of the breeding season has revealed that many harbour two common species of fleas: Ceratophyllus gallinae and Dasypsyllus gallinulae (Tyler \& Ormerod 1994). C. gallinae (the hen flea) is generally predominant, but D. gallinulae (the moorhen flea) is apparently more common in nests from wetter sites. The hen flea prefers dry sites. Breitenmoser-Wursten (Tyler \& Ormerod 1994) reported that attacks by fleas $D$. gallinulae were attributable to $21 \%$ of failures of first broods of Dipper in her study area in the northern Swiss Alps.
Fleas seem to be one of the main reasons that a nest is not reused the next season. In 199833 nests of Dipper were monitored in Hedmark, and in one nest, many fleas were observed. This nest was deserted after the laying of three eggs, and a pair had at the same time started breeding at the nearest locality (Øigarden 1999). This may be the same pair switching nest. In Hedmark county, Norway, 59 nests used in the 2002 breeding season were checked in spring 2003 and six (13,6 \%) of the nests were infected with fleas, i.e. the fleas were visible around the nest opening or were found on the hand after nest inspection (Øigarden 2003). None of these six nests was in use in 2003, and in five cases, another nest at the locality or at the neighbouring locality was in use. At some localities there is only one nesting place, for example a nest box. When these nesting places become empty unexpectedly, i.e. empty even in

a)

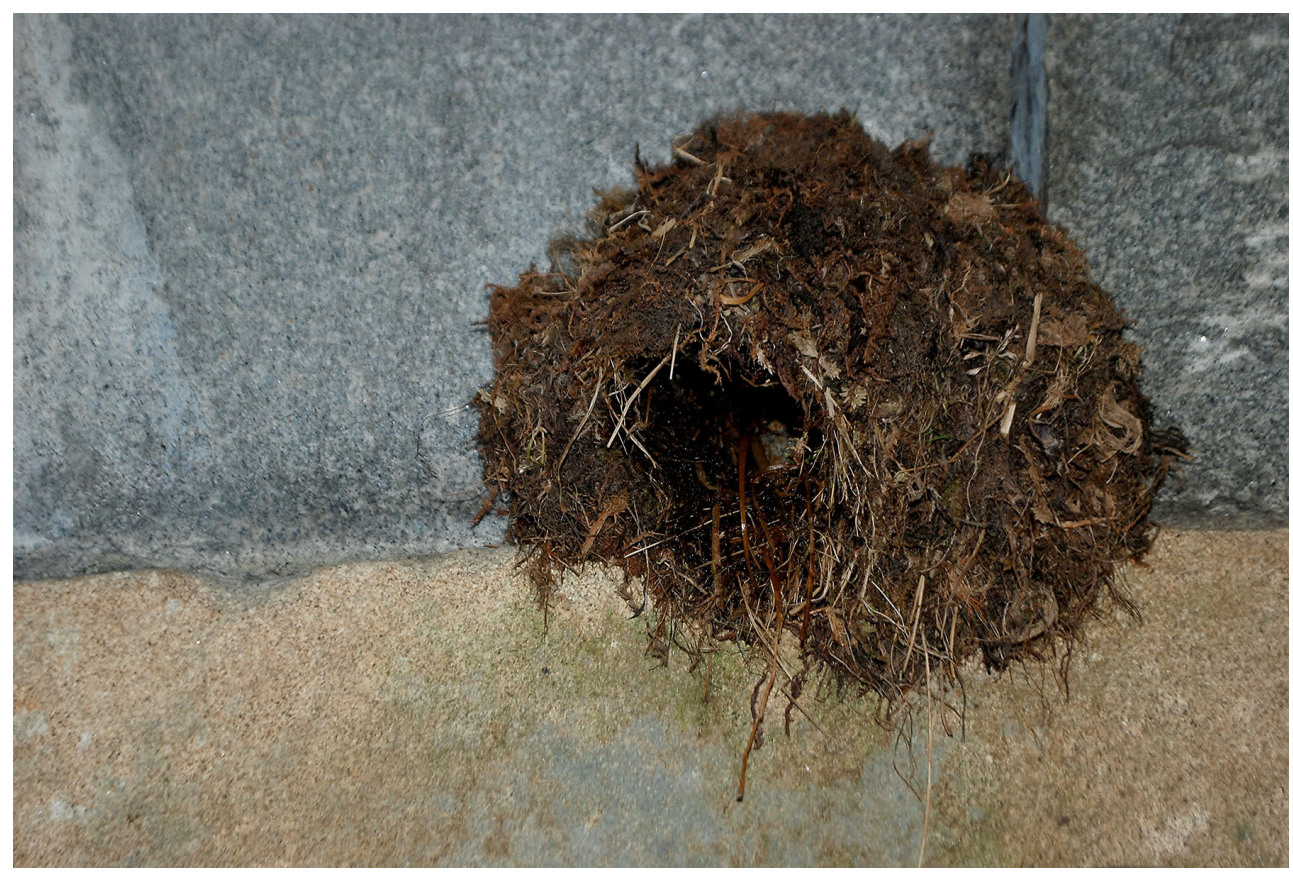

b)

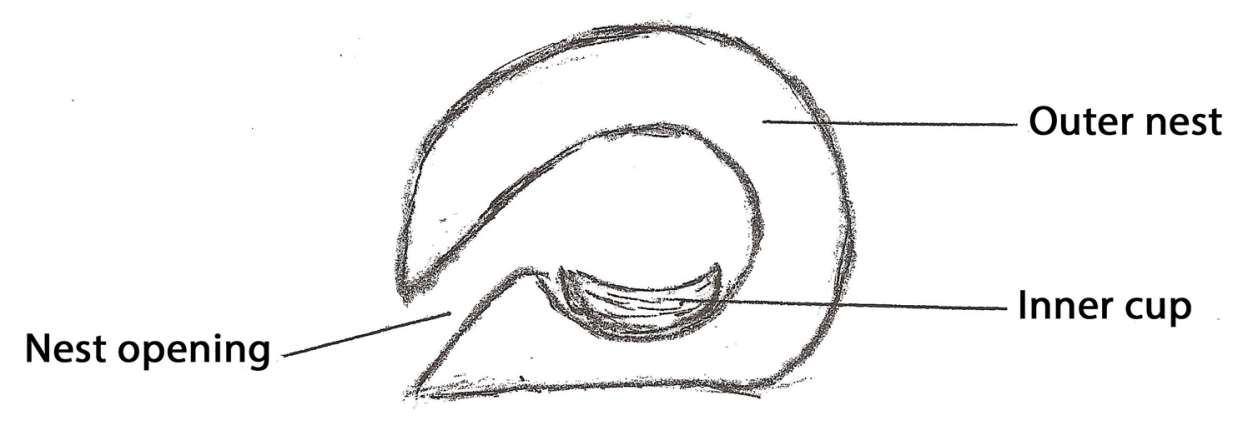

Figure 1. Dipper nest (a) is a domed structure of moss, c. 20 x 20 x $20 \mathrm{~cm}$, with an inner cup of grass. Photo: Trond Øigarden. Vertical cross-section (b) of Dipper nest. (after Walseng 1984). 
a year with a rising breeding population; then there are usually fleas in the nest (Jerstad pers. obs.). Little work is done on Dippers and fleas (Tyler \& Ormerod 1994), and there are no studies on this in Norway. In relation to the breeding biology of the Dipper, with a domed nest and strong fidelity to the nest location and the nest, we expect that fleas are common in Dipper nests. The aim of this study was to collect nest material in Southern Norway and Eastern Norway, to get an indication of flea species and number of fleas in Dipper nests in those two areas.

\section{MATERIAL AND METHODS}

\section{Study species}

The Dipper breeds throughout Norway, from the seashore to the subalpine zone (Gjershaug et al. 1994, Haftorn 1971). The clutch consists of five (4-7) eggs, laid in March-June. The incubation time is 16 (12-18) days, and the fledging period 20-24 days (Snow and Perrins 1998).

Dipper nests (Figure 1) are large, almost circular, domed structures made mainly from moss, c. $20 \times 20$ x $20 \mathrm{~cm}$, with an inner cup much like that of other passerine nests, built of grass and lined with leaves (Tyler \& Ormerod 1994). The nest is placed close to the water, on ledges, in cavities, below an overhang (earth or rock), behind waterfalls, on stones in the river, under bridges or in old dams. Artificial sites are much used where available; there are reports of 50-90\% use of man-made nest sites (Efteland \& Kyllingstad 1985, Øigarden 1999, Øigarden 2003, Tyler \& Ormerod 1994). The Dipper also uses nest-boxes. Nests in artificial sites and nests in nest-boxes more rarely collapse than nests in natural sites. Such nest sites are often drier than those in natural sites are. The Dippers frequently use the same nest for several years.

Nest sites close to waterfalls and nest sites without overhang are in this study categorized as wet sites, and nest sites under bridges, in hydroelectric power stations and in nest boxes are categorized as dry sites.

\section{Flea species}

C. gallinae is mostly found in dry nests, all over Norway (Mehl 1967a,b, and unpublished). D. gallinulae is most common at humid nest sites and particularly in areas with coastal climate (Tyler \& Ormerod 1994, Mehl unpublished data). Harper et al. (1992) point out that $D$. gallinulae is most common in the nest of birds mainly feeding on the ground. These include the Moorhen Gallinula chloropus, Grey Wagtail, Northern Wren Troglodytes troglodytes, European Robin Erithacus rubecula, Eurasian Blackbird Turdus merula and Common Redstart Phoenicurus phoenicurus. Most studies on birds and fleas involve nest boxes, often those occupied by tits (Tripet \& Richner 1999b, Wesołowski
\& Stanska 2001). D. gallinulae and C. gallinae are common parasites related to the nest box species, but the distribution of fleas varies according to the geography and host species. Mehl (1967a) also include C. garei in the most common bird fleas in Norway; this flea is mostly found in nests on the ground.

\section{Field work}

We sampled material in two areas; Hedmark/Akershus and Vest-Agder, Vest-Agder has a coastal climate with higher temperature and higher precipitation than Hedmark/Akershus. Sampling of nest material in Hedmark was done in April/May 2006 and 2007, in Akershus in December 2006 and in Vest-Agder in August 2007. All the eight nests from Hedmark were found under bridges, four of them in nest boxes. The one nest from Akershus was found at a natural site, close to a waterfall. In Vest-Agder eight nests were found at man-made sites, four of them in nest boxes, and three nests were found at natural sites, two of them close to waterfalls. Sampling conditions are different in the two areas. In Vest-Agder, we sampled nest material only in nests with breeding the same year as sampling. In Hedmark three nests were sampled the first spring after breeding, but for the rest of the nests we did not know whether the nests had been used last spring so we just had to sample what we found. The nest in Akershus was sampled the first winter after breeding. For details on sampling sites, see Table 1. In addition, we have material from one nest sampled in Nordland in 1922, three nests sampled in Akershus in 1969 and one nest sampled in Møre og Romsdal in 1971. The material from 1922 was sampled by Ole Ravnaa and is not part of any study, but the material from 1969 and 1971 was sampled by Mehl and is part of his collection of fleas from Norway. The flea collection is stored at the Natural History Museum, University of Oslo. The sampling method is described by Mehl (1970a). Nest material, i.e. most of the inner nest cup was collected and placed in a polyethlene bag. This bag was kept open and placed into another closed bag to enable the fleas to leap from the nest material into the outer bag. We used zip lock bags as the outer bag. The bags were stored in room temperature, until all fleas were dispersed out into the outer bag. Fleas were then identified to species and counted.

\section{Statistics}

Statistical testing was performed in $\mathrm{R}$ version 2.15 .2 ( $\mathrm{R}$ Development Core Team 2012).

\section{RESULTS}

We found four species of fleas in the nest material from Dipper nests at our study sites, Dasypsyllus gallinulae, Ceratophyllus gallinae, C. garei and Megabothris turbidus Rothschild, 1909. 
Table 1. Sampling sites, collection dates and descriptions of nest sites for Dipper nests examined for fleas in eastern and southern Norway.

\begin{tabular}{|c|c|c|c|c|c|c|c|}
\hline No. & Locality & River & County & $\begin{array}{l}\text { Collection } \\
\text { date } \\
\text { (dd.mm.yy) }\end{array}$ & Nest site & $\begin{array}{l}\text { Nest- } \\
\text { box }\end{array}$ & $\begin{array}{c}\text { Breeding } \\
\text { year }\end{array}$ \\
\hline 1 & Svarstadbua & Vestre Æra & Hedmark & 29.04 .06 & Under bridge & $\mathrm{x}$ & $?$ \\
\hline 2 & Nysætra & Vestre Æra & Hedmark & 04.05 .06 & Under bridge & & $?$ \\
\hline 4 & Gammelbuene & Ringsåsbekken & Hedmark & 11.05 .06 & Under bridge & $\mathrm{x}$ & Old nest \\
\hline 5 & Lindberget & Ringsåsbekken & Hedmark & 11.05 .06 & Under bridge & & $?$ \\
\hline 6 & Svartåa & Svartåa & Hedmark & 19.05 .06 & Under bridge & & $?$ \\
\hline 13 & Horka & Gjermåa & Akershus & 14.12 .06 & Close to waterfall & & 2006 \\
\hline 14 & Blikkberget & Krisma & Hedmark & 23.04 .07 & Pipe under road & $\mathrm{x}$ & 2006 \\
\hline 15 & Lindberget & Ringsåsbekken & Hedmark & 23.04 .07 & Under bridge & & 2006 \\
\hline 16 & Storbekk & Storbekken & Hedmark & 23.04 .07 & Under bridge & $\mathrm{x}$ & 2006 \\
\hline 20 & Sparkehylen & Gylandsvassdraget & Vest-Agder & 28.08 .07 & Under bridge & $\mathrm{x}$ & 2007 \\
\hline 21 & Fedåk & Gylandsvassdraget & Vest-Agder & 28.08 .07 & Under bridge & $\mathrm{x}$ & 2007 \\
\hline 22 & Nuland & Gylandsvassdraget & Vest-Agder & 28.08 .07 & Under bridge & $\mathrm{x}$ & 2007 \\
\hline 23 & Høyland & Gylandsvassdraget & Vest-Agder & 28.08 .07 & $\begin{array}{l}\text { Hydroelectric } \\
\text { power station }\end{array}$ & $\mathrm{x}$ & 2007 \\
\hline 24 & Krossli & Gylandsvassdraget & Vest-Agder & 28.08 .07 & Big stone & & 2007 \\
\hline 25 & Handeland & Møska & Vest-Agder & $28.08 .07 \mid$ & Pipe under road & & 2007 \\
\hline 26 & Vatland & Møska & Vest-Agder & 28.08 .07 & Under bridge & & 2007 \\
\hline 27 & Dragland & Skurvåa & Vest-Agder & 28.08 .07 & Under bridge & & 2007 \\
\hline 28 & Egilstad & Skurvåa & Vest-Agder & 28.08 .07 & Close to waterfall & & 2007 \\
\hline 29 & Fidja & Litlåna & Vest-Agder & 28.08 .07 & In old dam & & 2007 \\
\hline 30 & Grubbelia & Litlåna & Vest-Agder & 28.08 .07 & Close to waterfall & & 2007 \\
\hline
\end{tabular}

In the old material from 1922, 1969 and 1971 fleas were recorded in three Dipper nests, with two species: C. gallinae and D. gallinulae (see Table 2). In the new material from 2006 and 2007, we found three species of bird fleas and one mammalian flea species (see Table 3 ). D. gallinulae was recorded in six nests, $C$. gallinae was recorded in seven nests, $C$. garei was recorded in one nest and the mammalian flea $M$. turbidus was recorded in one nest. In Hedmark County, we only found $C$. gallinae, but in Vest-Agder county D. gallinulae was the predominant species, here $C$. gallinae was only found in one nest. In one nest from Vest-Agder County, we counted 3740 D. gallinulae fleas.

Our results support earlier findings, that $C$. gallinae prefers dry sites, and that $D$. gallinulae is more common on wetter sites. All nests with C. gallinae were under bridges and/or in nest boxes. Nests with $D$. gallinulae were more often on natural sites and especially nest number 29, which harboured a large count of $D$. gallinulae, was on a wet site. We found D. gallinulae only in Vest-Agder, which has a coastal climate, and not in Hedmark with inland climate.

To test for an effect of time of sampling, we used a two-sample Wilcoxon test (also called MannWhitney test) to compare the total number of fleas in nests sampled the same year as breeding (median = 13.5 , interquartile range $(\mathrm{IQR})=0-31.5, \mathrm{n}=12$ ) with nests sampled the first spring after breeding (median $=96, \mathrm{IQR}=64.5-107, \mathrm{n}=3$ ). A tendency was found indicating that nests sampled the next year had more fleas than those sampled the same season $(\mathrm{W}=31, \mathrm{p}$ $=0.067)$. Separate tests for single flea species showed

Table 2. Fleas from dipper nests, sampled in 1922, 1969 and 1971.

\begin{tabular}{lcccc}
\hline Locality and date & Nests/nests with fleas & Number of fleas & $\begin{array}{c}\text { Ceratophyllus } \\
\text { gallinae }\end{array}$ & $\begin{array}{c}\text { Dasypsyllus } \\
\text { gallinulae }\end{array}$ \\
\hline Ramnå 23 Aug. 1922 & $1 / 1$ & 16 & 16 & \\
Asker 20 June 1969 & $3 / 1$ & 129 & 68 & 61 \\
Kvanne 1 Aug. 1971 & $1 / 1$ & 388 & 84 & 489 \\
\hline Sum & $5 / 3$ & 533 & 849 \\
\hline
\end{tabular}


Table 3. Fleas from Dipper nests in Eastern Norway, sampled in 2006 and 2007, and Southern Norway, sampled in 2007.

\begin{tabular}{|c|c|c|c|c|c|c|}
\hline No. & Locality & Number of fleas & $\begin{array}{l}\text { Dasypsyllus } \\
\text { gallinulae }\end{array}$ & $\begin{array}{l}\text { Ceratophyllus } \\
\text { gallinae }\end{array}$ & $\begin{array}{l}\text { Ceratophyllus } \\
\text { garei }\end{array}$ & $\begin{array}{c}\text { Megabothris } \\
\text { turbidus }\end{array}$ \\
\hline 1 & Svarstadbu & 0 & & & & \\
\hline 2 & Nysætra & 0 & & & & \\
\hline 4 & Gammelbuene & 0 & & & & \\
\hline 5 & Lindberget & 189 & & 189 & & \\
\hline 6 & Svartåa & 9 & & 9 & & \\
\hline 13 & Horka & 14 & & 12 & 2 & \\
\hline 14 & Blikkberget & 96 & & 96 & & \\
\hline 15 & Lindberget & 118 & & 118 & & \\
\hline 16 & Storbekk & 33 & & 33 & & \\
\hline 20 & Sparkehylen & 13 & 13 & & & \\
\hline 21 & Fedåk & 88 & 69 & 19 & & \\
\hline 22 & Nuland & 22 & & & & 22 \\
\hline 23 & Høyland & 0 & & & & \\
\hline 24 & Krossli & 15 & 15 & & & \\
\hline 25 & Handeland & 26 & 26 & & & \\
\hline 26 & Vatland & 0 & & & & \\
\hline 27 & Dragland & 48 & 48 & & & \\
\hline 28 & Egilstad & 0 & & & & \\
\hline 29 & Fidja & 3740 & 3740 & & & \\
\hline 30 & Grubbelia & 0 & & & & \\
\hline \multicolumn{2}{|c|}{ Sum fleas (nests) } & $4411(20)$ & $3911(6)$ & $476(7)$ & $2(1)$ & $22(1)$ \\
\hline
\end{tabular}

that this effect was mainly driven by C. gallinae, for which a significant difference in the same direction was found (median $=0$ vs. 96, IQR $=64.5-107$ vs $0-0 ; \mathrm{W}$ $=31, \mathrm{p}=0.0026)$, whereas no significant differences were found for the other species (all $\mathrm{p}>0.16$; details not shown).

\section{DISCUSSION}

The two predominant species of fleas we have found are the same as reported from other studies on the Dipper (Tyler \& Ormerod 1994). Mehl (1967b) has found $C$. gallinae mainly on dry sites, above the ground as in nests of the Spotted Flycatcher Muscicapa striata or the Common Redstart. He has found D. gallinulae in nests of birds with the nest in low position, but also in the nest of for example the Long-tailed Tit Aegithalos caudatus (Mehl 1967c).

One nest harboured two specimens of Ceratophyllus garei; this species is as far as we know not reported previously from Dipper nests. Mehl (1967b, 1992) has found $C$. garei mainly in nests on the ground, for example in the nests of gulls and ducks. On the other hand we did not find any specimens of Ceratophyllus styx Rothschild, 1900, a Sand Martin flea reported from Dipper nests by Rothschild \& Clay (1952).

One nest with a small rodent flea (Megabothris turbidus) is probably accidental. The host of this flea may have used the nest either during the winter or after the departure of the birds.

In contrast to results reported in Tyler \& Ormerod (1994), there is an excess of D. gallinulae in our material, but this is mainly because of the high number of fleas in one nest. We found C. gallinae in seven nests and D. gallinulae in six nests, but $D$. gallinulae was not found in Hedmark County. This may be because D. gallinulae is mainly distributed in areas with coastal climate. The material sampled by Mehl (unpubl. data) supports this, he found $D$. gallinulae mainly distributed in the southern parts of Norway. There may be a sampling bias in the material, related to time of sampling, but the differences between the two areas could also be related to distribution differences in the two species and climatic differences of the two areas.

The very high number of $D$. gallinulae found in one nest shows that the fleas have a huge potential to reproduce under good conditions. Such large counts are occasionally recorded (Peus 1968, Rheinwald 1968), but published estimates of population size of fleas in bird nests are few. Harper et al. (1992) collected fleas from two nestbox population with nests of seven species (Coal Tit, Marsh Tit Poecile palustris, Great Tit, Blue Tit, Nuthatch Sitta europaea, Pied Flycatcher and Redstart) over a ten year periode, finding high numbers of $C$. gallinae (up to 3793 ind.), but the number of $D$. 
gallinulae never rose so high (up to 1102 ind.). Dippers use the outer nest for several years; they just build a new inner nest (Tyler \& Ormerod 1994). Dippers commonly throw out the used inner nest cup after the young have left, even if they do not start a second brood (Kurt Jerstad pers. obs.). When they do, they remove the entire inner nest cup, which may be an adaptation to minimize the flea problem.

To conclude, this study shows that flea infection in nests of Dipper can be substantial. More work is needed to get an understanding of the relationship between the Dipper and its ectoparasites. Factors to take into account are nest sites, reuse of nests, nest material (especially leaves used for lining of the nest), climatic variation and breeding success.

Acknowledgements. We are grateful to Lars Erik Johannessen for help with the statistics. We also thank Steffen Roth for comments on an earlier version of the manuscript.

\section{REFERENCES}

Brown, C.R., Brown, M.B. \& Rannala, B. 1995. Ectoparasites reduce long-term survival of their avian host. Proceedings of the Royal Society London B 262: 313-319.

Efteland, S. \& Kyllingstad, K. 1985. Fossekallbestanden i fare i nærmiljøet. Vår Fuglefauna 8: 139-141. (In Norwegian)

Fitze, P.S., Tschirren, B. \& Richner, H. 2004. Life history and fitness consequences of ectoparasites. Journal of Animal Ecology 73: 216-226.

Gjershaug, J. O., Thingstad, P. G., Eldøy, S. \& Byrkjeland, S. 1994. Norsk fugleatlas. Norsk Ornitologisk Forening, Klæbu. (In Norwegian)

Haftorn, S. 1971. Norges fugler. Universitetsforlaget, Oslo. (In Norwegian)

Harper, G.H., Marchant, A. \& Boddington, D.G. 1992. The ecology of the hen flea Ceratophyllus gallinae and the moorhen flea Dasypsyllus gallinulae in nestboxes. Journal of Animal Ecology 61: 317-327.

Heeb, P., Kölliker, M. \& Richner, H. 2000. Bird-ectoparasite interactions, nest humidity, and ectoparasite community structure. Ecology 81: 958-968.

Mappes, T., Mappes, J. \& Kotiaho, J. 1994. Ectoparasites, nest site choice and breeding success in the Pied Flycatcher. Oecologia 98: 147-149.

Mehl, R. 1967a. Lopper og taksvalereder i bergvegg. (Fleas (Siphonaptera) and nests of Delichon urbica on cliffs). Fauna 20: 168-175. (In Norwegian, English summary)

Mehl, R. 1967b. Ektoparasittiske undersøkelser på fugl og pattedyr i Syd-Varanger sommeren 1966. Fauna 20: 195-201. (In Norwegian, English summary)

Mehl, R. 1967c. Fleas (Siphonoptera) new to Norway. Norsk Entomologisk Tidskrift 14: 60-62.

Mehl, R. 1968. New records of fleas from Norway. Norsk Entomologisk Tidskrift 15: 70.

Mehl, R. 1970a. Om innsamling av insekter og midd på fugler og pattedyr. Fauna 23: 237-252. (In Norwegian, English summary)

Mehl, R. 1970b. Records of ectoparasitic insects and mites on birds and mammals in Norway. Norsk Entomologisk Tidsskrift 17: 109-113.

Mehl, R. 1992. Fleas (Siphonaptera) from seabirds and their nests in mainland Norway and Spitzbergen. NIPH Annals 15: 3-15.

Møller, A. P. \& Erritzøe, J. 1996. Parasite virulence and host immune defense: Host immune response is related to nest reuse in birds. Evolution 50: 2066-2072.

Oppliger, A., Richner, H. \& Christe, P. 1994. Effect of an ectoparasite on lay date, nest-site choice, desertion and hatching success in the Great Tit (Parus major). Behavioral Ecology 5: 130-134.

Pacejka, A.J., Gratton, C.M. \& Thompson, C. 1998. Do potentially virulent mites affect House Wren (Troglodytes aedon) reproductive success? Ecology 79: 1797-1806.

Peus, F. 1968. Zur Kenntnis der Flöhe Deutchlands. II. Faunistik und Ökologie der Vogelflöhe (Insecta, Siphonaptera). Zoologisches Jahrbuch Systematikk 95: 571-633. (In German)

R Development Core Team (2012). R: A language and environment for statistical computing. R Foundation for Statistical Computing, Vienna, Austria. ISBN 3-90005107-0, URL http://www.R-project.org/.

Rheinwald, G. 1968. Flohbefall bei höhlenbrütenden Singvögeln. Vogelwelt 89: 147-149. (In German)

Richner, H., Oppliger, A. \& Christe, P. 1993. Effect of an ectoparasite on reproduction in Great Tits. Journal of Animal Ecology 62: 703-710.

Rothschild, M. \& Clay, T. 1952. Fleas, flukes and cuckoos. A study of bird parasites. Collins, London.

Rytkönen, S., Lehtonen, R. \& Orell, M. 1998. Breeding Great Tits Parus major avoid nestboxes infested with fleas. Ibis 140: 687-690.

Snow, D. W. \& Perrins, C. M. 1998. The birds of the Western Palearctic, concise edition. Oxford University Press, Oxford.

Tomás, G., Merino, S. Moreno, J. \& Morales, J. 2007. Consequences of nest reuse for parasite burden and female health and condition in Blue Tits, Cyanistes caeruleus. Animal Behaviour 73: 805-814.

Tripet, F. \& Richner, H. 1997a. The coevolutionary potensial of a "generalist" parasite, the hen flea Ceratophyllus gallinae. Parasitology 115: 419-427.

Tripet, F. \& Richner, H. 1997b. Host responses to ectoparasites: food compensation by parent Blue Tits. Oikos 78: 557-561.

Tripet, F. \& Richner, H. 1999a. Density-dependent processes in the population dynamics of a bird ectoparasite Ceratophyllus gallinae. Ecology 80: 1267-1277.

Tripet, F. \& Richner, H. 1999b. Dynamics of hen flea Ceratophyllus gallinae subpopulations in Blue Tit nests. Journal of Insect Behavior 12: 159-174.

Tyler, S. \& Ormerod, S. 1994. The dippers. T \& A D Poyser, London. 
Walseng, B. 1984. Reir, reirplassering og ungeproduksjon hos fossekallen Cincluc cinclus i Lyngdalsvassdraget, Vest-Agder. Unpublished master thesis, University of Oslo. (In Norwegian)

Wesołowski, T. \& Stanska, M. 2001. High ectoparasite loads in hole-nesting birds - a nestbox bias? Journal of Avian Biology 32: 281-285.
Øigarden, T. 1999. Fossekallen i Hedmark; er hekkesuksessen påvirket av sur nedbør? Avd. for landbruks- og naturfag. Høgskolen i Hedmark, Blæstad. (In Norwegian)

Øigarden, T. 2003. Fossekallens valg av reirplass og gjenbruk av reir. Kornkråka 33: 150-152. (In Norwegian)

Received 4 September 2013. Accepted 30 October 2013 